\title{
Identifikasi Tomato infectious chlorosis virus dan Tomato chlorosis virus melalui Reverse Transcription Polymerase Chain Reaction dan Analisis Sikuen Nukleotida
}

\author{
Identification of Tomato infectious chlorosis virus and Tomato \\ chlorosis virus by Reverse Transcription Polymerase Chain Reaction \\ and Nucleotide Sequence Analysis
}

\author{
Sari Nurulita, Gede Suastika* \\ Institut Pertanian Bogor, Bogor 16680
}

\begin{abstract}
ABSTRAK
Insidensi penyakit klorosis mulai banyak ditemukan di daerah sentra produksi tomat di Jawa Barat. Pengamatan pada tanaman sakit menunjukkan adanya gejala menyerupai infeksi Tomato infectious chlorosis virus (TICV) dan Tomato chlorosis virus (ToCV). Penelitian ini bertujuan mengidentifikasi TICV dan ToCV yang berasosiasi dengan penyakit klorosis pada tanaman tomat di daerah Jawa Barat (Cipanas, Lembang, Garut) melalui metode reverse transcription polymerase chain reaction (RT-PCR) dan analisis sikuen nukleotida. Berdasarkan hasil RT-PCR menggunakan primer spesifik TICV-CF/ TICV-CR dan ToCV-CF/ToCV-CR diperoleh berturut-turut pita DNA berukuran $417 \mathrm{pb}$ dan $360 \mathrm{pb}$ dari sampel asal Cipanas. Sikuen nukleotida dari DNA produk RT-PCR tersebut memastikan bahwa penyakit klorosis pada tanaman tomat di Cipanas berasosiasi dengan infeksi TICV dan ToCV. Analisis homologi sikuen nukleotida dan filogenetika menunjukkan bahwa isolat TICV asal Cipanas berada dalam satu kelompok dengan isolat TICV asal Jepang dan Spanyol, sedangkan isolat ToCV asal Cipanas berada dalam satu kelompok dengan isolat ToCV asal Amerika.
\end{abstract}

Kata kunci: Bemisia tabaci, crinivirus, filogenetika, Trialeuroides vaporariorum

\begin{abstract}
Tomato chlorosis disease was found more frequent on production area in West Java recently. Observation in the field showed typical symptoms of Tomato infectious chlorosis virus (TICV) and Tomato chlorosis virus (ToCV). The objective of this research is to identify TICV and ToCV associated with chlorosis disease on tomato plants in West Java (Cipanas, Lembang and Garut) using reverse transcription polymerase chain reaction (RT-PCR) method and nucleotide sequence analysis. DNA target of $417 \mathrm{bp}$ and $360 \mathrm{bp}$ was successfully amplified only from Cipanas sample using specific primers, TICV-CF/TICV-CR and ToCV-CF/ToCV-CR, respectively. Sequence analysis confirmed that chlorosis disease in Cipanas was associated with TICV and ToCV infection. Nucleotide sequence and phylogenetic analysis showed that TICV from Cipanas has high homology to and belongs to the same group with TICV from Japan and Spain; whereas ToCV from Cipanas has high homology to and belongs to the same group with ToCV from America.
\end{abstract}

Key words: Bemisia tabaci, crinivirus, phylogenetic, Trialeuroides vaporariorum

*Alamat penulis korespondensi: Departemen Proteksi Tanaman, Fakultas Pertanian, Institut Pertanian Bogor, Kampus Darmaga, Jalan Kamper, Bogor 16680

Tel: 0251 8629364, Faks:0251 8629362, Surel: gedesuast@yahoo.com 


\section{PENDAHULUAN}

Tomat merupakan salah satu tumbuhan perdu Solanaceae yang rentan terhadap berbagai organisme pengganggu tanaman. Beberapa tahun terakhir ini penyakit baru yang disebabkan oleh Tomato infectious chlorosis virus (TICV) dan Tomato chlorosis virus (ToCV) mulai banyak ditemukan di pertanaman tomat di Indonesia (Hartono dan Wijonarko 2007). Infeksi TICV pertama kali muncul dan dilaporkan dari sejumlah tempat di negara bagian California, Amerika Serikat pada tahun 1993 (Duffus et al. 1996), sedangkan ToCV pertama kali ditemukan pada pertanaman tomat di bagian Utara Florida, Amerika Serikat sekitar tahun 1996 (Wintermantel dan Wisler 2006). Setelah itu, daerah sebar TICV dan ToCV dilaporkan semakin meluas meliputi beberapa negara di Eropa dan Asia (EPPO 2005).

Kedua virus, TICV dan ToCV, termasuk dalam genus Crinivirus, famili Closteroviridae (Wisler et al. 1998b ; Wintermantel dan Wisler 2006). Infeksi TICV dan ToCV menyebabkan gejala yang hampir sama pada tanaman di lapangan, yaitu menguning pada bagian interveinal daun (Duffus et al. 1996), bintikbintik nekrotik kecil (Wintermantel dan Wisler 2006), mengeriting (Hirota et al. 2010), dan gejala lanjut dicirikan dengan warna daun merah kecokelatan (Wisler et al. 1998a). Walaupun gejala yang ditimbulkan tidak terdapat pada bunga dan buah, tetapi gejala yang terdapat pada daun dapat mengganggu proses fotosintesis. Hal ini menyebabkan penurunan produksi buah secara nyata (Wisler et al. 1998a). Penularan dan penyebaran kedua virus di lapangan terjadi melalui serangga vektor. Walaupun menyebabkan gejala yang hampir sama, TICV dan ToCV ditularkan oleh serangga vektor yang berbeda. Tomato infectious chlorosis virus hanya ditularkan oleh satu spesies serangga, yaitu Trialeurodes vaporariorum (Duffus et al. 1996), sedangkan ToCV dapat ditularkan oleh beberapa spesies kutukebul, yaitu Bemisia tabaci, T. vaporarium (Wintermantel dan Wisler 2006), dan T. abutilonea (Wisler et al. 1998b).
Insidensi penyakit klorosis mulai banyak ditemukan di daerah sentra produksi tomat di Jawa Barat di antaranya di daerah Cipanas, Lembang, dan Garut. Pengamatan pada tanaman sakit menunjukkan adanya gejala berupa menguningnya jaringan interveinal daun terutama pada daun di bagian bawah tanaman. Gejala lebih lanjut menunjukkan perubahan warna klorosis dari kekuningan menjadi merah kecokelatan pada daun. Penelitian dilakukan untuk mengidentifikasi TICV dan ToCV dari tanaman tomat.

\section{BAHAN DAN METODE}

Sampel daun tomat diambil dari daerah Jawa Barat, yaitu Cipanas, Lembang dan Garut.

\section{Deteksi Virus dengan RT-PCR}

Tahapan RT-PCR terdiri atas ekstraksi RNA total, sintesis complementary (c) DNA, amplifikasi DNA virus target, dan visualisasi hasil amplifikasi. Ekstraksi RNA total dilakukan menggunakan Qiagen RNeasy Plant Mini Kit (Qiagen Inc., Valencia-California, US). Sintesis cDNA dilakukan dengan menyiapkan bahan reaksi yang terdiri atas $3.2 \mu \mathrm{L} \mathrm{H}_{2} \mathrm{O}, 1 \mu \mathrm{L}$ bufer reverse-transcription 10x, $0.35 \mu \mathrm{L}$ DTT $50 \mathrm{mM}, 2 \mu \mathrm{L}$ dNTP $10 \mathrm{mM}$, $0.35 \mu \mathrm{L}$ MMuLV, $0.35 \mu \mathrm{L}$ RNAse inhibitor, $0.75 \mu \mathrm{L}$ oligo d(T) $10 \mathrm{mM}$, dan $2 \mu \mathrm{L}$ RNA total untuk setiap reaksi. Sintesis cDNA dilakukan pada mesin thermal cycler (GeneAmp PCR System 9700, Applied Biosystem) dengan program $25^{\circ} \mathrm{C}$ selama 5 menit, $42{ }^{\circ} \mathrm{C}$ selama 60 menit, dan $70^{\circ} \mathrm{C}$ selama 15 menit.

Tahapan deteksi virus dilanjutkan dengan amplifikasi virus target, yaitu TICV dan ToCV, masing-masing menggunakan primer spesifik, yaitu TICV-CF ( 5 ' - AATCGGTAGTGACACGAGTAG CATC-3') dan TICV-CR (5'-CTTCAAAC ATCCTCCATCTGCC-3') untuk TICV dan ToCV-CF (5'-GTGTCAGGCCATTGTAAAC CAAG-3') dan ToCV-CR (5'-CACAAAGCG TTTCTTTTCATAAGCAGG-3') untuk ToCV. Produk amplifikasi yang diharapkan adalah bagian selubung protein dengan ukuran 
$417 \mathrm{pb}$ dan $360 \mathrm{pb}$, berturut-turut untuk TICV dan ToCV. Komposisi bahan dalam reaksi

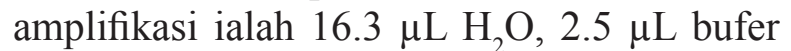
10x yang mengandung $\mathrm{Mg}^{2+}, 0.5 \mu \mathrm{L}$ dNTP $10 \mathrm{mM}, 2.5 \mu \mathrm{L}$ sucrose cresol 10x, primer forward dan reverse masing-masing $1 \mu \mathrm{L}$, $0.2 \mu \mathrm{L}$ taq polymerase $5 \mathrm{U}_{\mu \mathrm{L}^{-1}}$, dan $1 \mu \mathrm{L}$ cDNA sebagai template. Program amplifikasi terdiri atas 30 siklus dengan tahapan predenaturasi pada suhu $94{ }^{\circ} \mathrm{C}$ selama 4 menit, denaturasi (fase pemisahan utas DNA) pada suhu $94{ }^{\circ} \mathrm{C}$ selama 1 menit, annealing (pengintegrasian primer) pada suhu $62{ }^{\circ} \mathrm{C}$ selama 1 menit, elongation (sintesis untaian DNA baru) pada suhu $72{ }^{\circ} \mathrm{C}$ selama 2 menit, dilanjutkan tahap pasca extention $72{ }^{\circ} \mathrm{C}$ selama 10 menit dan $4{ }^{\circ} \mathrm{C}$ untuk suhu penyimpanan. Visualisasi produk amplifikasi dilakukan menggunakan $1 \%$ gel agarosa dalam $0.5 x$ bufer TBE (Trisborate EDTA) dengan elektroforesis selama 60 menit pada $50 \mathrm{~V}$.

Analisis Sikuen Nukleotida dan Filogenetika

Produk PCR dari masing-masing sampel dikirim ke PT Macrogen Inc. (Seoul, Korea) untuk dilakukan sikuensing nukleotida. Hasil sikuen nukleotida kemudian digunakan untuk analisis kesejajaran dengan sikuen nukleotida TICV atau ToCV yang telah dipublikasikan di GenBank dengan program basic local alignment search tools (BLAST). Data sikuen nukleotida yang terpilih kemudian dimodifikasi dan analisis spesifisitas nukleotida dilakukan dengan program multiple alignment pada CluctalW BioEdit V.7.0.5 dan CLC Seq Viewer V.0.2 sebelum dilakukan analisis filogenetika. Analisis filogenetika menggunakan program CLC Seq Viewer V.0.2 berdasarkan pendekatan Unweighted Pair Group Method with Arithmetic Mean (UPGMA).

\section{HASIL}

\section{TICV dan ToCV pada Tomat}

Sampel daun tomat yang diambil dari daerah Cipanas, Lembang dan Garut menunjukkan gejala klorosis dengan jaringan interveinal mengalami penguningan. Deteksi dengan RT-PCR hanya berhasil mengamplifikasi pita DNA dari sampel asal Cipanas. Pita DNA berukuran $\sim 400 \mathrm{pb}$ dan $\sim 360 \mathrm{pb}$ didapatkan dari amplifikasi menggunakan pasangan primer berturut-turut TICV-CF/TICV-CR dan ToCV-CF/ToCV-CR (Gambar 1). Kedua pasang primer tersebut dirancang untuk mengamplifikasi bagian gen protein selubung masing-masing virus (Hirota et al. 2010). DNA hasil amplifikasi tersebut selanjutnya digunakan untuk sikuensing nukleotida.

\section{Sikuen Nukleotida dan Filogenetika TICV}

Analisis sikuen nukleotida dengan ClustalW menunjukkan bahwa gen protein selubung TICV asal Cipanas memiliki homologi yang tinggi dengan isolat-isolat TICV yang berasal dari negara lain seperti

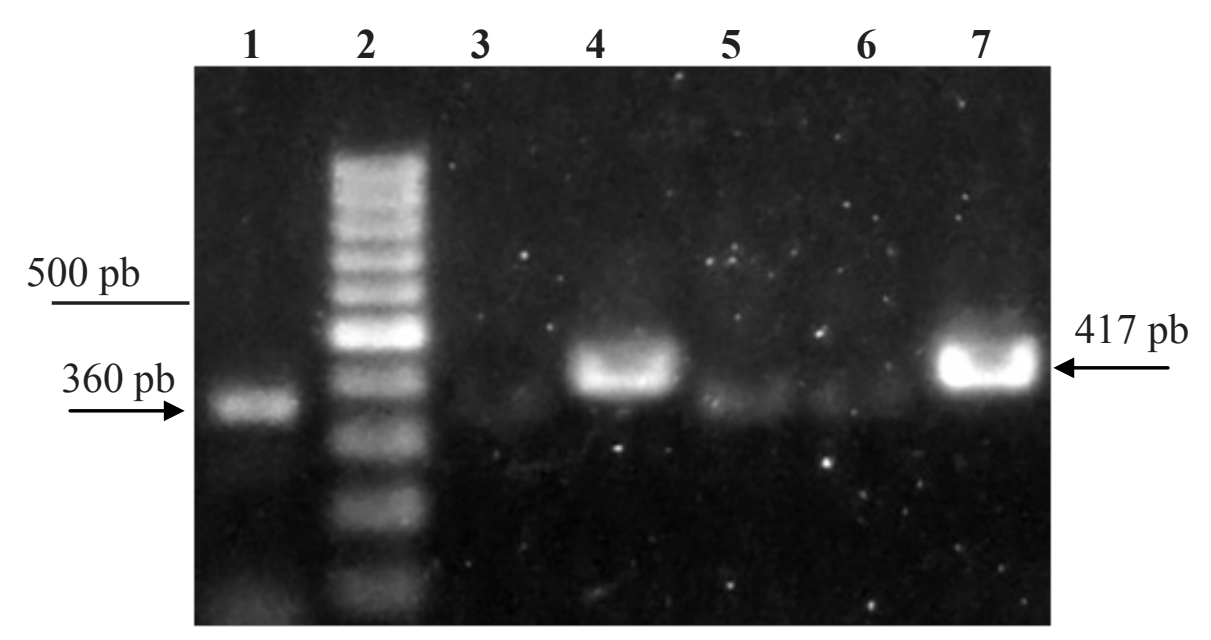

Gambar 1 Pita DNA hasil amplifikasi menggunakan teknik RT-PCR dengan primer spesifik ToCV (kolom 1), TICV (kolom 3 s/d 7), dan penanda DNA 100 pb (kolom 2). Sampel terdiri atas sampel daun tomat asal Cipanas $(1,4,7)$, Lembang (3), Garut (5 dan 6). 
Amerika, Italia, Jepang, Perancis, dan Spanyol (Gambar 2). Hasil analisis penyejajaran sikuen nukleotida juga memperkuat hal tersebut, dengan nilai penyejajaran berkisar 99-100\% yang mengindikasikan kemiripan sikuen nukleotida antarisolat yang sangat tinggi (Tabel 1). Hasil penyejajaran asam amino isolat-isolat TICV juga menunjukkan hasil yang sama dengan penyejajaran sikuen nukleotida (Gambar 3). Oleh karena itu, dapat dinyatakan bahwa isolat TICV yang menginfeksi pertanaman tomat di Cipanas

\begin{abstract}
AMERIKA INDONESIA ITALIA JEPANG PERANCIS SPANYOL

1:ACCTCAACTGACTICTACACATTCGTTTTTAAAAATCGGTAGTGACACGAGTAGCATCAA 60 1:ACCTCAACTGACITCTACACAITCGITITTAAAAATCGGTAGTGACACGAGTAGCATCAA 60 1:ACCTCAACTGACITCTACACAITCGITITIAAAAATCGGTAGTGACACGAGIAGCATCAA 60 1 :ACCTCAACTGACITCTACACATTCGITITTAHAAACGGIAGTGACACGAGTAGCATCAA 60 1 :ACCICAACTGACTICTACACATTCGITITTAAAAATCGIAGTGACACGAGTAGCATCAA 60 1:ACCTCAACTGACITCTACACAITCGITITTAAAAATCGGIAGTGACACGAGTAGCATCAA 60

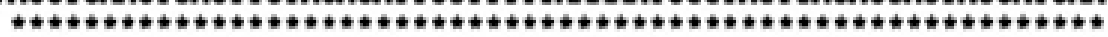

AMERIKA INDONESIA ITALIA JEPANG PERANCIS SPANYOL

AMERIKA INDONESIA ITALIA JEPANG PERANCIS SPANYOL

AMERIKA INDONESIA ITALIA JEPANG PERANCIS SPANYOL

AMERIKA INDONESIA ITALIA JEPANG PERANCIS SPANYOL

AMERIKA INDONESIA ITALIA JEPANG PERANCIS SPANYOL

AMERIKA INDONESIA IIALIA JEPANG PERANCIS SPANYOL

61: ACCTGTAAAAAATGATGTGITAATAGAAAAAATAAAAACCTTTGAAGATATCCTGGTCGC 120 61: ACCTGTAAAAAATGATGTGITAATAGAAAAAATAAAAACCTTTGAAGATATCCIGGTCGC 120 61: ACCTGIAAANAATGATGTGITAATAGAAAAAATARAAACCITTGAAGATATCCTGGTCGC 120 61:ACCTGIANANAATGATGTGTTAATAGAANAATAAAAACCTTTGAAGATATCCTGGTCGC 120 61: ACCTGTANANAATGATGTGTTAATAGAAANAATAAAAACCTTTGAAGATATCCTGGTCGC 120 61: ACCTGIANANAATGATGIGITAATAGAAANAATAAAAACCITTGAAGATATCCIGGICGC 120

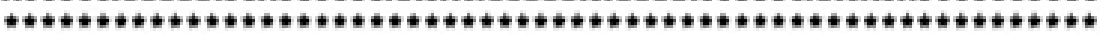

121: AGATGITGAAGATCATARAGACAIAGAGGAAGATAGATCARAATATGAACIACCTGACGI 180 121: AGCTGITGAAGATCATANAGACATAGAGGAAGATAGATCANAATATGAACTACCTGACGT 180 121: AGATGITGAAGATCATARAGACATAGAGGAAGATAGATCARATATGAACTACCTGACGT 180 121: AGCTGITGAAGATCATAAAGACATAGAGGAAGATAGATCANAATATGAACTACCTGACGI 180 121: AGCTGITGAAGATCATAAAGACATAGAGGAAGATAGATCAAAATATGAACTACCTGACGT 180 121: AGCTGITGAAGATCATARAGACATAGAGGAAGATAGATCARAATATGAACTACCTGACGT 180

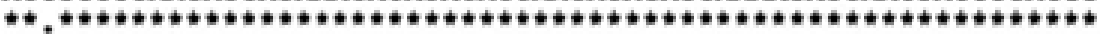

181: AACGTCTGAATITCAACAGGAAGATAAGATAAAACAMGTGAGGTTGTATGACGTGITGGA 240 181: AACGTCTGAAITICAACAGGAAGATAAGATAAAACAAGTGAGGTTGIATGACGIGITGGA 240 181: AACGTCTGAATITCAACAGGAAGATAAGATANAACAAGTGAGGITGIATGACGTGITGGA 240 181: AACGTCTGAAITICAACAGGAAGATARGATAAAACAAGTGAGGTIGIAIGACGIGITGGA 240 181: AACGTCTGAATITCAACAGGAAGATAAGATAAAACAAGTGAGGITGIATGACGTGITGGA 240 181: AACGICTGAAIITCAACAGGAAGATAAGATAAAACAAGIGAGGITGIATGACGTGITGGA 240

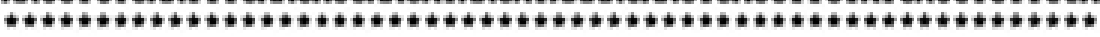

241: ITGTGGTGGCAAATCTITCICCACTITAACCATTAACGCAAAATTIAAGCCITICAAATT 300 241: ITGIGGIGGCANATCITICICCACIITAACCAITAACGCAAAATITAMGCCIITCAAATI 300 241: ITGIGGTGGCANATCITTCICCACIIIAACCATIAACGCARAATTIAAGCCIITCAAATT 300 241: ITGTGGIGGCAAATCITTCTCCACTITARCCATTAACGCARAATTIAAGCCITTCARATI 300 241: ITGTGGTGACAAATCITTCTCCACIITAACCATIAACGCAAAATITARGCCIITCAAATT 300 241: ITGIGGIGGCANAICITTCICCACIIIAACCAITAACGCARAAITIAAGCCIITCANAIT 300

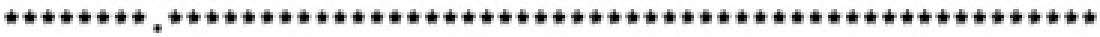

301: IGTAGATATGGITAACTTATTGCAGITGTGGTATGGAGACTCAAAATCTAACAATITAGA 360 301: IGTAGATATGGITAACTTATTGCAGITGTGGIATGGAGACTCAAAATCIAACAAIITAGA 360 301: IGIAGATAIGGIIAACTIATIGCAGITGIGGIAIGGAGACTCAAAAICIAACAAIITAGA 360 301: IGIAGATATGGITAACTTATTGCAGITGIGGTATGGAGACTCAAAATCTAACAATITAGA 360 301: TGIAGATAIGGITAACTTATTGCAGITGIGGIATGGAGACTCAAAAICTAACAAIIIAGA 360 301: IGIAGAIATGGITAACITAITGCAGITGIGGIAIGGAGACTCAAAATCTAACAAIITAGA 360

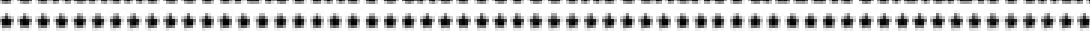

361: GCTGTTGATACGITATGATGAATCACAACGAGATAGATTGACACTTCAACTATGTAT 361: GCTGITGATACGIIATGATGAATCACAACGAGATAGATIGACACITCAACTATGIAT 361 : GCIGITGATACGIIATGATGAATCACAACGAGATAGATIGACACTTCAACTATGIAT 361: GCTGITGATACGITATGATGAATCACAACGAGATAGATTGACACTTCAACTATGTAT 361: GCIGITGATACGITATGATGAATCACAACGAGATAGATIGACACTICAACTATGTAT 361: GCIGITGATACGIIATGATGAATCACAACGAGATAGATIGACACTTCAACIATGTAT

Gambar 2 Perbandingan sikuen nukleotida sebagian gen protein selubung TICV asal CipanasIndonesia, Amerika, Italia, Jepang, Perancis, dan Spanyol menggunakan program BioEdit V.7.0.5 
(selanjutnya disebut TICV isolat Indonesia) kemungkinan adalah spesies yang sama dengan TICV dari Amerika, Italia, Jepang, Perancis, dan Spanyol.

Analisis filogenetika pada kladogram menunjukkan bahwa hubungan kekerabatan keenam isolat tersebut terbagi menjadi dua kelompok (Gambar 4). Kelompok pertama terbagi menjadi dua subkelompok, yaitu subkelompok I yang terdiri atas isolat asal
Jepang, Spanyol, dan Indonesia; sedangkan subkelompok II hanya terdiri atas isolat asal Perancis. Kelompok kedua terdiri atas isolat asal Amerika dan Italia. Kedekatan hubungan kekerabatan isolat TICV asal Indonesia dengan isolat TICV asal Jepang dengan homologi 100\% sesuai dengan hasil penelitian sebelumnya yang dilaporkan oleh Hartono dan Wijonarko (2007).

Tabel 1 Tingkat kesamaan sikuen nukleotida sebagian gen protein selubung TICV asal Indonesia, Amerika, Italia, Jepang, Perancis, dan Spanyol

\begin{tabular}{llcccccc}
\hline \multirow{2}{*}{ No aksesi } & \multirow{2}{*}{ Asal isolat } & \multicolumn{5}{c}{ Tingkat kesamaan (\%) } \\
\cline { 3 - 7 } & & Indonesia & Amerika & Italia & Jepang & Perancis & Spanyol \\
\hline- & Indonesia & - & & & & & \\
FJ815441 & Amerika & 99 & - & & & \\
EU881362 & Italia & 99 & 100 & - & & & \\
AB085603 & Jepang & 100 & 99 & 99 & - & - & \\
DQ355217 & Perancis & 99 & 99 & 99 & 99 & 99 & - \\
FJ542305 & Spanyol & 100 & 99 & 99 & 100 & 99 \\
\hline
\end{tabular}

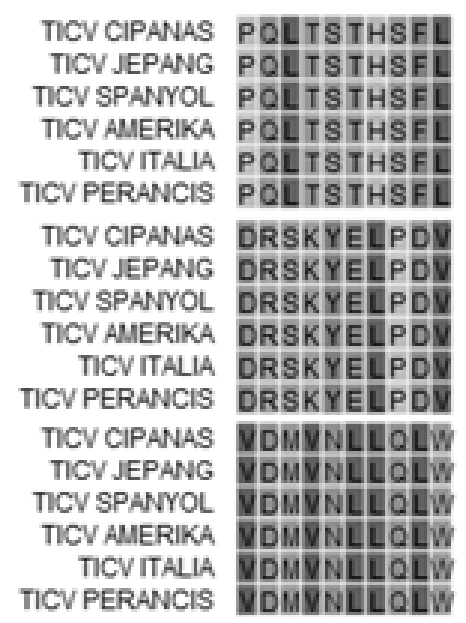

\begin{tabular}{l} 
KIGSDTSSIK \\
KIGSDTSSIK \\
KIGSDTSSIK \\
KIGSDTSSIK \\
KIGSDTSSIK \\
KIGSDTSSIK \\
\hline TSEFQQEDKI \\
TSEFQQEDKI \\
TSEFQQEDI \\
TSEFQQERI \\
TSEFQQEDKI \\
TSEFQQEDKI \\
YGDSKSNNLE \\
YGDSKSNNLE \\
YGDSKSNNLE \\
YGDSKSNNLE \\
YGDSKSNNLE \\
YGDSKSNNLE
\end{tabular}

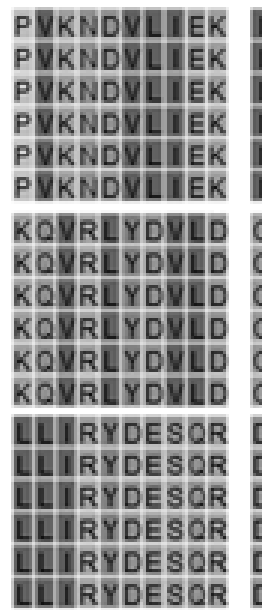

\begin{tabular}{|c|}
\hline 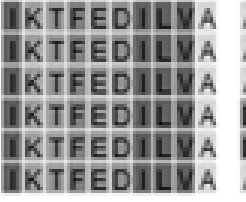 \\
\hline $\begin{array}{l}\text { CGGKSFSTLT } \\
\text { CGGKSFSTLT } \\
\text { CGGKSFSTLT } \\
\text { CGGKSFSTLT } \\
\text { CGGKSFSTLT } \\
\text { CGDKSFSTLT }\end{array}$ \\
\hline $\begin{array}{lll}\text { DRLTLQLC } & 138 \\
\text { DRLTLQLC } & 138 \\
\text { DRLTLQLC } & 138 \\
\text { DRLTLQLC } & 138 \\
\text { DRLTLOLC } & 138 \\
\text { DRLTTLOLC } & 138\end{array}$ \\
\hline
\end{tabular}

Gambar 3 Penyejajaran asam amino TICV isolat asal Cipanas dengan isolat asal Jepang, Spanyol, Amerika, Italia, dan Perancis menggunakan program CLC Seq Viewer V.7.0.2.

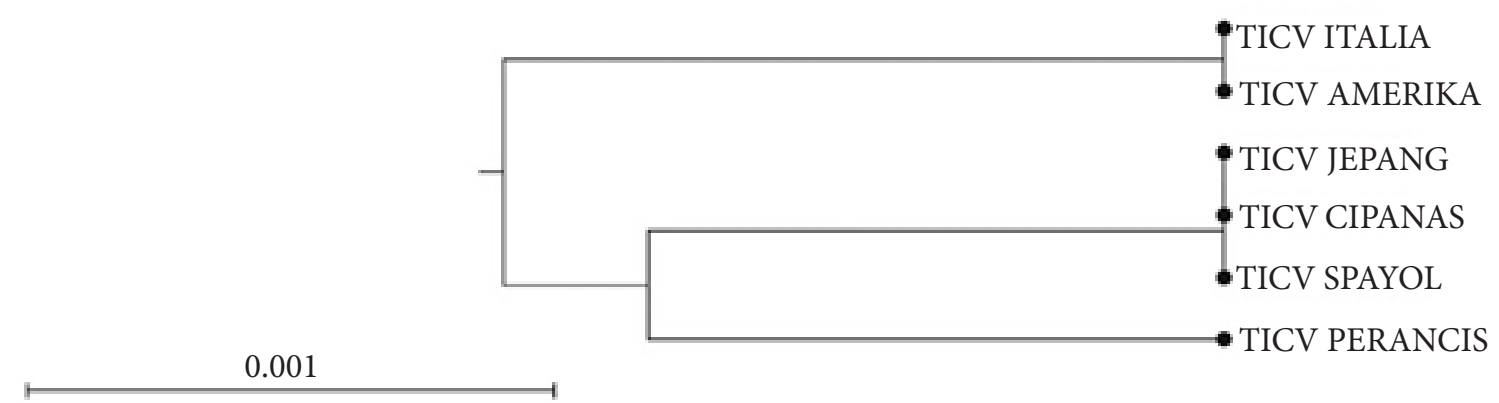

Gambar 4 Pohon filogenetika berdasarkan sikuen nukleotida sebagian gen protein selubung isolat-isolat TICV asal Cipanas-Indonesia, Amerika, Italia, Jepang, Perancis, dan Spanyol menggunakan program CLC Seq Viewer V.7.0.2. 
Sikuen Nukleotida dan Filogenetika ToCV

Analisis sikuen nukleotida menunjukkan bahwa gen protein selubung ToCV asal Cipanas memiliki homologi yang tinggi dengan isolat-isolat TICV yang berasal dari negara lain seperti Amerika, Jepang, dan Perancis (Gambar 5). Hasil analisis penyejajaran sikuen nukleotida menunjukkan bahwa isolat ToCV asal Cipanas memiliki nilai penyejajaran yang tinggi, yaitu $98-100 \%$, dengan ToCV dari Jepang, Perancis, dan Amerika (Tabel 2). Hasil penyejajaran asam amino juga menunjukkan hasil yang sama dengan penyejajaran sikuen nukleotida (Gambar 6). Dengan demikian dapat dinyatakan bahwa isolat ToCV yang menginfeksi pertanaman tomat di Cipanas (selanjutnya disebut ToCV isolat Indonesia) kemungkinan adalah spesies yang sama dengan ToCV dari Amerika, Jepang, dan Perancis. Lebih lanjut, analisis filogenetika menunjukkan bahwa kekerabatan isolat ToCV asal Amerika dan Jepang lebih dekat dengan isolat $\mathrm{ToCV}$ asal Indonesia dibandingkan dengan ToCV asal Perancis (Gambar 7).

\section{PEMBAHASAN}

Penyakit klorosis yang disebabkan oleh TICV dan ToCV dilaporkan menyebabkan penurunan produksi tomat yang cukup nyata sejak awal 1990 di beberapa negara bagian di Amerika Serikat terutama California dan Florida (Duffus et al. 1996, Wisler et al. 1998a, Wintermantel dan Wisler 2006). Daerah persebaran TICV dan ToCV saat ini semakin meluas hingga ke Eropa dan Asia, meliputi beberapa negara seperti Italia (Wisler et al. 1998a), Yunani (Dovas et al. 2002), Spanyol (Lozano et al. 2006), dan Taiwan (Tsai et al. 2004). Penyakit klorosis pada tanaman tomat di Indonesia pertama kali dilaporkan oleh Hartono dan Wijonarko (2007) di daerah

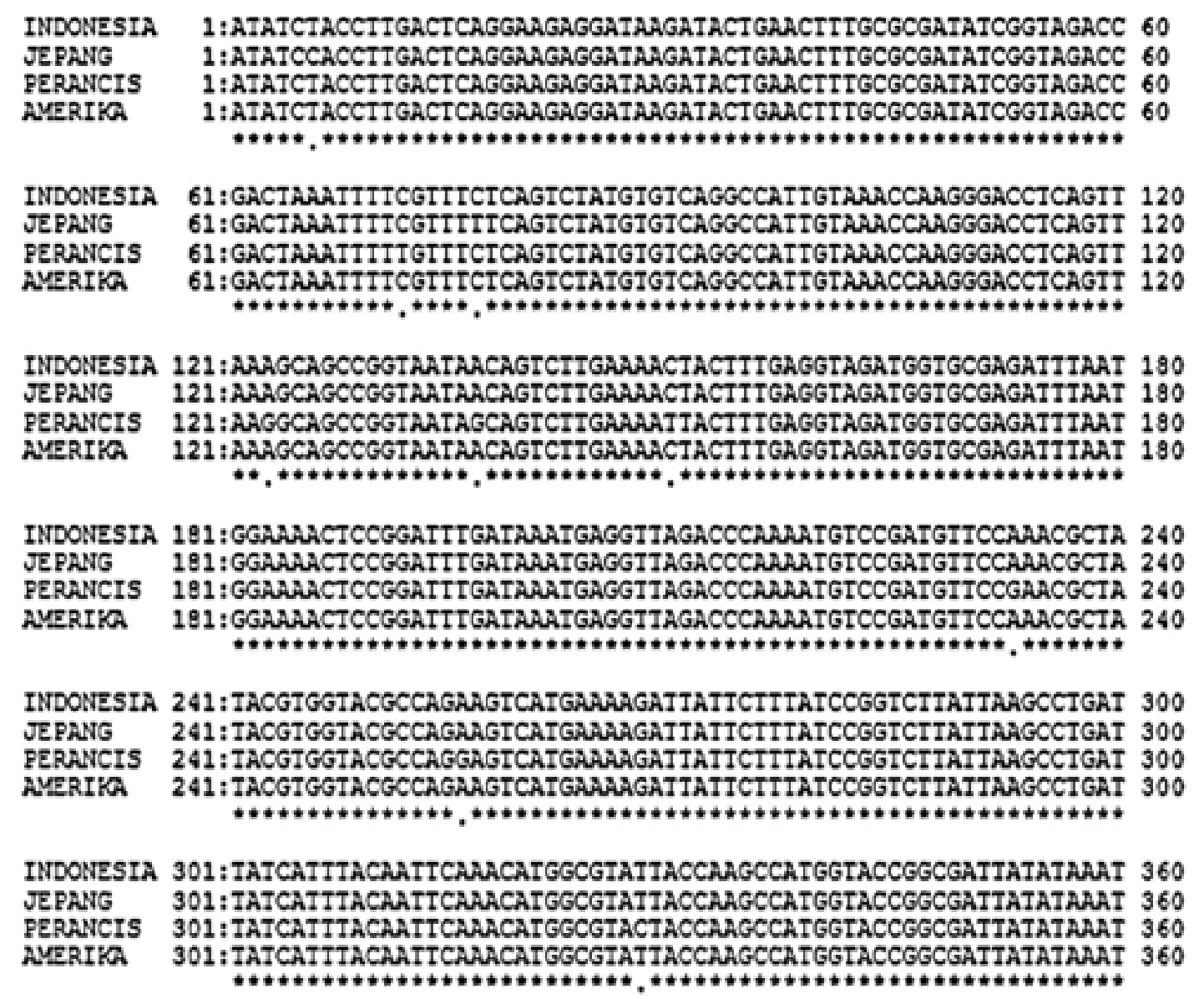

Gambar 5 Perbandingan sikuen nukleotida sebagian dari gen protein selubung ToCV asal Cipanas-Indonesia, Jepang, Perancis, dan Amerika menggunakan program BioEdit V.7.0.5 
Tabel 2 Tingkat kesamaan sikuen nukleotida sebagian dari gen protein selubung ToCV asal Indonesia, Jepang, Perancis, dan Amerika

\begin{tabular}{cccccc}
\hline \multirow{2}{*}{ No aksesi } & Asal isolat & \multicolumn{4}{c}{ Tingkat kesamaan (\%) } \\
\cline { 3 - 6 } & & Indonesia & Jepang & Perancis & Amerika \\
\hline- & Indonesia & - & & \\
AB513443 & Jepang & 99 & - & \\
FM206382 & Perancis & 98 & 97 & - & \\
DQ234675 & Amerika & 100 & 99 & 98 & - \\
\hline
\end{tabular}

\begin{tabular}{|c|c|c|c|c|}
\hline $\begin{array}{l}\text { ToCVCipanas } \\
\text { ToCVJepang } \\
\text { ToCVAmerika } \\
\text { ToCVPerancis }\end{array}$ & $\begin{array}{l}\text { ISTLTQEEDK } \\
\text { ISTLTQEEDK } \\
\text { ISTLTQEEDK } \\
\text { ISTITQEEDK }\end{array}$ & 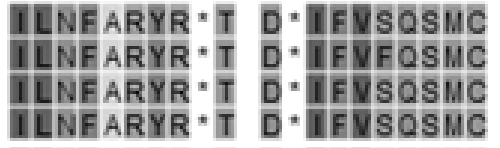 & $\begin{array}{l}\text { QAIVNQGTS } \\
\text { QAIVNQGTSV } \\
\text { QAIVNQGTS } \\
\text { QAIVNQGISN }\end{array}$ & $\begin{array}{l}\text { KAAGNNSLEN } 50 \\
\text { KAAGNNSLEN } 50 \\
\text { KAAGNNSLEN } 50 \\
\text { KAAGNSSLEN } 50\end{array}$ \\
\hline $\begin{array}{l}\text { ToCVCipanas } \\
\text { ToCVJepang } \\
\text { ToCVAmerika } \\
\text { ToCVPerancis }\end{array}$ & $\begin{array}{l}\text { ISTLTQEEDK } \\
\text { ISTLTQEEDK } \\
\text { ISTLTQEEDK } \\
\text { ISTITLEEDK }\end{array}$ & 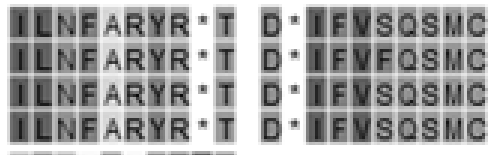 & $\begin{array}{l}\text { QAIVNQGTSN } \\
\text { QAIVNQGTSV } \\
\text { QAIVNQGTS } \\
\text { QAIVNQGISN }\end{array}$ & $\begin{array}{l}\text { KAAGNNSLEN } 50 \\
\text { KAAGNNSLEN } 50 \\
\text { KAAGNNSLEN } 50 \\
\text { KAAGNSSLEN } 50\end{array}$ \\
\hline $\begin{array}{l}\text { ToCVCipanas } \\
\text { ToCVJepang } \\
\text { ToCVAmerika } \\
\text { ToCVPerancis }\end{array}$ & 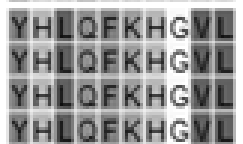 & $\begin{array}{l}\text { PSHGIGDYIN } 120 \\
\text { PSHGIGDYIN } 120 \\
\text { PSHGIGDYIN } 120 \\
\text { PSHGIGDYIN } 120\end{array}$ & & \\
\hline
\end{tabular}

Gambar 6 Penyejajaran asam amino ToCV isolat asal Cipanas dengan isolat asal Jepang, Amerika, dan Perancis menggunakan program CLC Seq Viewer V. 7.0.2.

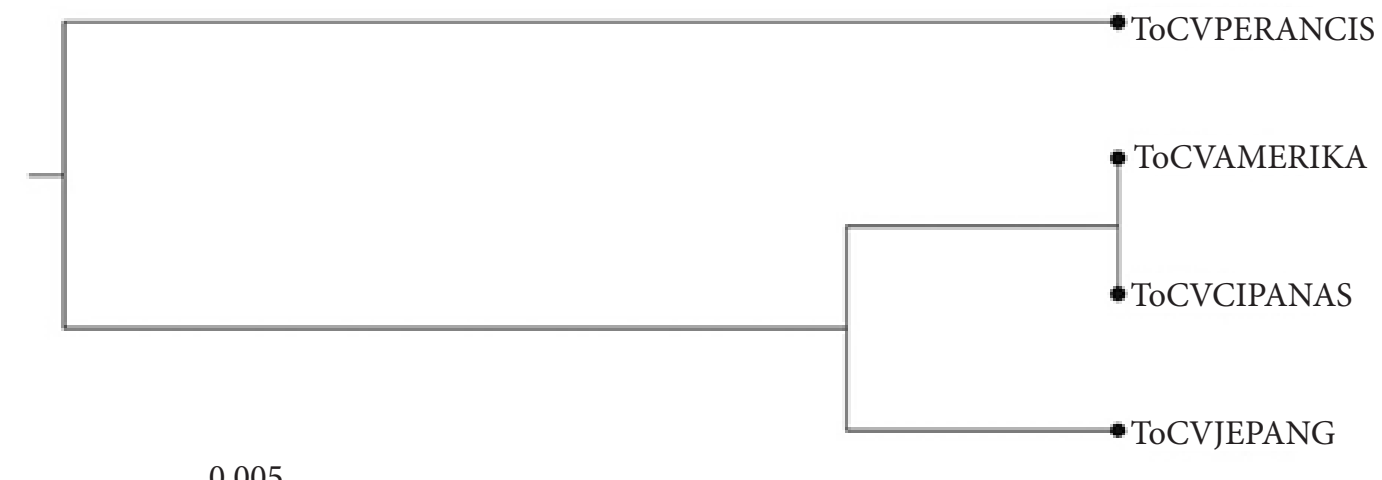

Gambar 7 Pohon filogenetika berdasarkan sikuen nukleotida sebagian gen protein selubung isolat-isolat ToCV asal Cipanas-Indonesia, Jepang, Perancis, dan Amerika menggunakan program CLC Seq Viewer V.7.0.2.

Magelang, Jawa Tengah. Penyakit klorosis ini pada awalnya disebut sebagai penyakit ungu karena gejala lanjut pada daun menunjukkan warna merah kecokelatan hingga keunguan. Gejala klorosis juga ditemukan di sentra pertanaman tomat di Jawa Barat seperti di daerah Cipanas, Lembang, dan Garut (Suastika et al. 2010). Lebih lanjut pada penelitian ini infeksi TICV dan ToCV hanya berhasil dideteksi dari sampel tanaman tomat asal Cipanas.

Penelitian mengenai penularan dan kisaran inang TICV dan ToCV mengindikasi potensi kedua virus untuk menyebar luas dan cepat. Tanaman komoditas penting lain yang rentan terhadap TICV ialah kentang (Solanum tuberosum) dan lettuce (Lactuca sativa) (Li et al. 1998). Kisaran inang ToCV meliputi berbagai tanaman dari famili Aizoaceae, Amaranthaceae, Apocynaceae, Chenopodiaceae, Compositae, Plumbaginaceae, dan Solanaceae (Wintermantel dan Wisler 2006). Li et al. (1998) juga melaporkan bahwa gulma Chenopodium capitatum dapat terinfeksi TICV, sedangkan 
gulma Physalis ixocarpa dan P. peruviana dilaporkan merupakan inang ToCV (Trenado et al. 2007). Penularan kedua virus terjadi melalui serangga vektornya kutukebul (Hemiptera: Aleyrodidae). TICV ditularkan oleh T. vaporariorum (Duffus et al. 1996), sedangkan ToCV ditularkan oleh beberapa spesies kutukebul B. tabaci, T. abutilonea, dan T. vaporarium (Wisler et al. 1998b, Wintermantel dan Wisler 2006) walaupun $B$. tabaci merupakan vektor yang paling efisien.

Kedua virus yang dapat menyebabkan gejala klorosis pada tanaman tomat dapat dibedakan melalui metode deteksi molekular dan pengamatan gejala pada tanaman indikator $N$. benthamiana dan $N$. clevelandii (Wisler et al. 1998b). Metode RT-PCR menggunakan primer spesifik untuk TICV dan ToCV banyak digunakan untuk mendeteksi infeksi kedua virus pada tanaman tomat dengan gejala klorosis. Dovas et al. (2002) merancang pasangan degenerate primer HS-11/HS-12 yang dapat mendeteksi baik TICV maupun ToCV karena primer tersebut mengenali daerah dengan konservasi yang tinggi antara kedua virus, yaitu heat shock protein 70 . DNA produk amplifikasi menggunakan pasangan primer HS-11/HS-12 selanjutnya digunakan untuk deteksi spesifik dengan metode nestedPCR menggunakan primer TIC-3/TIC4 dan ToC-5/ToC-6, berturut-turut untuk TICV dan ToCV. Dalmon et al. (2005) berhasil mendeteksi TICV dan ToCV pada tanaman tomat di Perancis menggunakan primer spesifik yang mengamplifikasi bagian gen protein selubung untuk TICV dan gen HSP70 untuk ToCV. Pasangan primer yang digunakan untuk mendeteksi kedua virus dari sampel tanaman tomat asal Jawa Barat dalam penelitian ini ialah ToCV-CF/ToCV-CR dan TICV-CF/ TICV-CR seperti yang digunakan oleh Hirota et al. (2010) untuk mendeteksi TICV dan ToCV pada tanaman tomat di Jepang. Kedua pasang primer tersebut mengamplifikasi bagian gen protein selubung dengan tingkat konservasi yang tinggi.

Melalui metode RT-PCR dan analisis sikuen nukleotida dapat disimpulkan bahwa penyakit klorosis pada tanaman tomat di
Cipanas, Jawa Barat berasosiasi dengan infeksi TICV dan ToCV, seperti yang sudah dilaporkan terjadi di beberapa negara lainnya. Isolat TICV asal Indonesia (Cipanas) tersebut memiliki hubungan kekerabatan yang dekat dengan TICV asal Jepang dan Spanyol, sedangkan isolat ToCV asal Cipanas memiliki hubungan kekerabatan yang dekat dengan isolat ToCV asal Amerika.

\section{DAFTAR PUSTAKA}

Dalmon A, Bouyer S, Cailly M, Girard M, Lecoq H, Desbiez C, Jacquemond M. 2005. First report of Tomato chlorosis virus and Tomato infectious chlorosis virus in tomato crops in France. Plant Dis. $89(11): 1243$. DOI: http://dx.doi. org/10.1094/PD-89-1243C.

Dovas CI, Katis NI, Avgelis AD. 2002. Multiplex detection of crinivirus associated with epidemics of a yellowing disease of tomato in Greece. Plant Dis. 86(12):1345349. DOI: http://dx.doi.org/10.1094/ PDIS.2002.86.12.1345.

Duffus JE, Liu HY, Wisler GC. 1996. Tomato infectious chlorosis virus-a new clostero-like virus transmitted by Trialeurodes vaporariorum. Eur J Plant Pathol. 102:219-226. DOI: http://dx.doi. org/10.1007/BF01877960.

[EPPO] European and Mediterranean Plant Protection Organization. 2005. Tomato chlorosis crinivirus. Bull EPPO. 35: 439-441. DOI: http://dx.doi.org/10.1111/ j.1365-2338.2005.00888.x.

Hartono S, Natsuki T, Sayama H, Atarashi H, Okuda S. 2003. Yellowing disease of tomatoes caused by Tomato infectious chlorosis virus newly recognized in Japan. J Gen Plant Pathol. 69: 61-64. DOI: http:// dx.doi.org/10.1007/s10327-002-0015-x.

Hartono S, Wijonarko A. 2007. Karakterisasi biologi molekuler Tomato infectious chlorosis virus penyebab penyakit kuning pada tanaman tomat di Indonesia. Akta Agrosia. 2:139-146.

Hirota T, Natsuaki T, Murai T, Nishigawa H, Niibori K, Goto K, Hartono S, Suastika 
G, Okuda S. 2010. Yellowing disease of tomato caused by Tomato chlorosis virus newly recognized in Japan. J Gen Plant Pathol. 76:168-171. DOI: http://dx.doi. org/10.1007/s10327-010-0219-4.

Li RH, Wisler GC, Liu HY, Duffus JE. 1998. Comparison of diagnostic techniques for detecting tomato invectious chlorosis virus. Plant Dis. 82(1):84-86. DOI: http:// dx.doi.org/10.1094/PDIS.1998.82.1.84.

Lozano G, Moriones E, Navas-Castillo J. 2006. Complete nucleotide sequence of the RNA2 of the Crinivirus tomato chlorosis virus. Arch Virol. 151:581-587. DOI: http://dx.doi.org/10.1007/s00705005-0690-y.

Suastika G, Hartono S, Nishigawa H, Natsuaki T. 2010. Yellowing disease outbreaks in tomato in Indonesia associated with infection of Tomato chlorosis virus and Tomato infectious chlorosis virus. Di dalam: Abstract ISSAAS International Congress 2010: Agricultural Adaptation in Response to Climate Change; 4-8 Nov 2010; Sanur, Bali, Indonesia. Sanur: ISSAAS.

Trenado HP, Fortes IM, Louro D, NavasCastillo J. 2007. Physalis ixocarpa and $P$. peruviana, new natural hosts of Tomato chlorosis virus. Eur J Plant Pathol. 118: 193-196. DOI: http://dx.doi.org/10.1007/ s10658-007-9129-5.

Tsai WS, Shih SL, Green SK, Hanson P. 2004. First report of the occurrence of Tomato infectious chlorosis virus in Taiwan. Plant Dis. 88:311. DOI: http://dx.doi. org/10.1094/PDIS.2004.88.3.311B.

Wintermantel WM, Wisler GC. 2006. Vector specificity, host range, and genetic diversity of Tomato chlorosis virus. Plant Dis. 90:814-819. DOI: http://dx.doi. org/10.1094/PD-90-0814.

Wisler GC, Duffus JE, Liu HY, Li RH. 1998a. Ecology and epidemiology of whiteflytransmitted closteroviruses. Plant Dis. 82(3):270-280. DOI: http://dx.doi. org/10.1094/PDIS.1998.82.3.270.

Wisler GC, Li RH, Liu HY, Lowry DS, Duffus JE. 1998b. Tomato chlorosis virus: a new whitefly-transmitted, phloem-limited, bipartite closterovirus of tomato. Phytopathol. 88:402409. DOI: http://dx.doi.org/10.1094/ PHYTO.1998.88.5.402. 